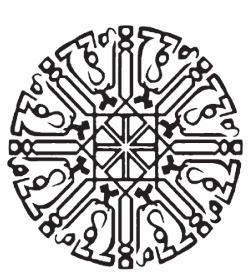

\title{
Fatwa DSN MUI in Managing the Dispute Settlement of Sharia Economic in Indonesia Through Basyarnas
}

\author{
Nunung Radliyah, Dewi Nurul Musjtari, Ro'fah Setyowati \\ Faculty of Law, University of Lampung, \\ Faculty of Law, Universitas Muhammadiyah Yogyakarta, \\ Faculty of Law, University of Diponegoro, \\ nunungradliyah@yahoo.com \\ dewinurulmusjtari@umy.ac.id \\ rofah_undip@yahoo.com
}

\begin{abstract}
Abstrak
Sharia Council is an institution that plays a role in securing the standard of Sharia in every Islamic Financial institution in the world. In Indonesia, the role is conducted by the National Sharia Council(DSN) established by the Indonesian Ulema Council (MUI) in 1998, strengthened by the Decree of the MUI Leadership Board. Kep-754/MUI/II/1999 dated February 10, 1999. The existence of MUI DSN in managing the settlement of sharia banking disputes has not been fully recognized by the people of Indonesia. It can be seen in the implementation of sharia contracting in sharia banking has not yet decided dispute resolution option through National Syariah Arbitration Board (BASYARNAS). The purpose of writing a paper is to know the legal basis of the binding force of the Fatwa DSN in arranging the settlement of dispute Sharia Economy in Indonesia through BASYARNAS and its consequences for the Islamic financial institutions (LKS) who disobey the fatwa DSN. This research is a normative research with the philosophical, juridical and sociological approach. Data analysis with qualitative descriptive. The results of this study indicate that the legal basis of the power of the DSN Fatwa in regulating the settlement of Sharia Banking disputes is Article 26 of Law No. 21 Th. 2008 and Article 31 of Decree of the Board of Managing Directors of Bank Indonesia Number 32/34/1999. There will a negative impact for LKS do not comply with the content of the DSN Fatwa, such as the difficulty in carry out its activities, aside of negatively influencing the performance and level of credibility of DPS in LKS.
\end{abstract}

Kata Kunci: Fatwa DSN, Dispute Settlement, Sharia Economy, BASYARNAS, Indonesia. 


\section{A. INTRODUCTION}

\section{Background}

The Indonesian Ulema Council (MUI) serves as a forum for deliberation and gathering of scholars, zuama and Muslim intellectuals in protecting the ummah and developing an Islamic life, as a vessel representing Muslims in relationships and consultations among religious believers and as a giver of fatwas to Muslims and government, both requested and unsolicited.

The role of the MUI itself based on Presidential Regulation No. 151 of 2014 on Funding Assistance the Activities of the Indonesian Ulema Council determine what is meant by the Majelis Ulama Indonesia (hereinafter MUI) is a forum for deliberation of ulema, leaders and Muslim intellectuals in protecting the ummah and developing an Islamic life and increasing participation Muslims in national development. MUI is a partner of the government in organizing an Islamic development program.

The profile of the MUI website explains that the $\mathrm{MUI}$ is a venue or assembly that brings together scholars, zuama, and Indonesian Muslim scholars to unite the movements and steps of Indonesian Muslims in realizing shared ideals. Besides, it is mentioned that the MUI as a forum for deliberation of scholars, zuama and Muslim scholars strive to:

a. Providing guidance to the Muslims in realizing the religious and social life that is blessed by Allah Subhanahu wa Ta'ala;

b. Providing counsel and fatwa on religious and social matters to the Government and society, increasing activities for the realization of Islamic ukhwah and inter-religious harmony in consolidating national unity and unity;

c. Become a liaison between ulema and umaro (government) and reciprocal interpreters between people and governments to succeed national development;

d. Increase cooperation between organizations, Islamic institutions and Muslim intellectuals in providing guidance to the community, especially Muslims by holding consultations and information on a reciprocal basis.

In the dedication ceremony of MUI, further explained the existence of the five functions and the main role of MUI is:
a. As an heir to the duties of the Prophets (Warasatul Anbiya);
b. As a fatwa giver (Mufti);
c. As mentors and servants of the people (History wa khadim al ummah);
d. As the movement of Islah wa al Tajdid;
e. As the enforcer amar ma'ruf and nahi munkar.

If we analyze carefully between the grund norms or staatsides or the staats fundamental norm of the norms of the Indonesian legal system with the teachings 
of Islam, it will be found extraordinary identity, especially because the basic or core of Islamic teachings is tawhid or belief in God and its attributes, as also embraced by the Indonesian legal system (Rajafi, 2013). It can be adapted to the first Precept of Pancasila (Five Principles) which means that in running the life of the state, to God, based on the accepted and recognized religion in Indonesia.

The government, in protecting the Muslim of Indonesia seeks some regulations that support the relationship between human being and Allah. MUI as an effort to help the embodiment of sharia law that accompanies the national law has a good role with its function that applies the rules of Sharia in the form of Fatwa. If it refers to the type and hierarchy as stipulated in the provisions of Article 1 No. 2 of Law Number 12 of 2011 concerning on the Establishment of the Law on Legislation, the position of the MUI Fatwa is not a type of legislation that has binding legal force. This means that the MUI fatwa is not a state law that has sovereignty that can be imposed for all people, MUI fatwa also has no sanctions and should not be obeyed by all citizens. As a socio-political force existing in the constitutional infrastructure. MUI fatwa is only binding and obeyed by the community of Muslims who feel have a bond to the MUI itself.

The legality of the MUI fatwa cannot and can be forced to be obeyed by all Muslims. The fatwa itself is essentially nothing more than an opinion and a mere thought, of the individual ulama or the institution of ulama, which may be followed or simply ignored altogether. Based on one of the national jurists' opinion which quoted by the author is the opinion of Moh. Mahfud MD, Professor of Constitutional Law, Chairman of the Constitutional Court of the Republic of Indonesia 2008-2013 also has a similar opinion that from the point of view of constitution and law, fatwa Majelis Ulama Indonesia (MUI) binding and cannot be imposed through law enforcement (Mahfud MD, 2016).

If it is related to the judiciary, he explains that the MUI's Fatwa before the court can be used as a statement and/or expert opinion, even doctrine, in order to prove the concrete-individual case (in concreto), not as an abstract-general rule. As according to Atho 'Mudzhar, the fatwa usually tends to be dynamic because it is a response to new developments that are being confronted by society (Ahmad Rafiq, 2015).

The role of fatwa has a strategic scope for Islamic economic activities in Islamic finance transactions in Indonesia. As a provision that supports the implementation of Islamic fundamental law, fatwas help realize the regulation of sharia economic activities to the people of Indonesia, especially the Muslim community. The role of Fatwa in supporting the implementation of sharia law in Indonesia is very diverse forms, for example in the implementation of contract implementation.

The ideal contract in the national sharia contract, language, the word "akad" is derived from the Arabic, al-'Aqd which is used in many meanings, the whole of which returns 
to the meaning of the bond or the merging of two things. This understanding includes all types of commitments, whether derived from two or more parties such as contracts of sale, leases and aqad marriage and the like; or commitments from one party only, such as an oath contract, nadzar, talak, akad giving gifts, shadaqah and others, including personal commitments to carry out all religious duties and abandon all restrictions in religion. According to Ibn Abidin, the contract is an engagement stipulated by ijab and qabul based on the sharia provisions that affect the object (Mardani, 2015).

The Qur'an prescribes the legal basis of sharia contracts which one of its verses is as follows: QS. Al-Maidah (5): 1: "O you who believe, fill the aqad-aqad It is lawful for your livestock, except that which will be read to you (That Is so) by not making any hunt when you are doing Hajj. God set the laws according to His will. "In Article 21 of the Supreme Court Regulation no. 2 of 2008 concerning the Compilation of Sharia Economic Law (KHES), regulates the principles of Sharia Contract (Akad) as follows:

a. Ikhtiyari/voluntary; self-will and no coercion;

b. Amanah/keep the promise; a timely implementation;

c. Ikhtiyati/caution; there is a careful consideration;

d. Luzum/unchanged; the purpose of the contract is clear so as to avoid the practice of speculation;

e. All profitable; a contract is created to satisfy the interests of the parties without any harmful manipulation of one party;

f. Taswiyah/equality; the parties have equal standing and equal rights and obligations; Transparency; there is open responsibility;

g. Ability; the implementation of the contract in accordance with the ability of the parties and does not cause excessive burden;

h. Taisir/amenity, meaning each contract provides convenience for the parties in fulfilling their rights and obligations;

i. Good faith; not hitting traps or other bad things;

j. For halal causes; not contrary to law and not haram.

In a special meaning, the contract has three pillars, namely two parties that do akad (al-'qid), object of akad (mahallul 'aqd), and pronunciation (shighah) akad. As details:

1. Two Contracting Parties.

The point is that two people are directly involved in the transaction. Both of these people must be eligible so that the transaction is considered valid. The terms are:

a) Rashid (able to distinguish which is good and bad for him). It is marked with maturity (baligh) and is not in an under pressure. The person who is banned because it is considered idiot or bankrupt total, then if he is doing the contract, then the akad is not valid; 
b) Voluntary and not forced. Akad committed under duress is invalid;

c) The contract is deemed valid and legally enforceable, if it does not have khiyar (voting right/option). Such as khiyar syarath (the right to choose a requirement), khiyar disgrace and the like;

d) The object of akad (Mahallul Aqd/al-Ma'qûd 'alaihi).

Something that becomes the object of the contract, sometimes in the form of property, goods and sometimes non-goods or in the form of benefits (services). For example, goods sold in contracts of sale or purchase or leased in the contract of lease and the like. This object must also be eligible, just said the contract is legitimate. The terms are:

2. The object of the contract is something that can be transacted according to the sharia. This requirement was agreed upon by figh scholars. Author Bidâyatul Mujtahid (2/166), Ibn Rushd rahimahullah said, "(If the object of the contract) goods, then (the condition is) may be traded. ... whereas (if the object of the contract is) the benefit (service) then it must be from something that is not prohibited sharia. On this issue, there are several issues that have been agreed upon and some are still disputed. Among those agreed upon (by the 'Ulema') is the cancellation of the lease contract for all benefits (services) used for something that is haram. Likewise, all benefits (services) are forbidden by the sharia, such as wages weeping the body. Based on this, if the object of the contract cannot be transferred by sharia, then the contract is not valid. For example, in the Mu'awadhah contract (business transaction), the object must be a valuable item, entirely owned by the transactor and not related to the rights of others. Based on this, the scholars of jurisprudence prohibit some form of the following transactions;

a. If the object of the contract is an independent human being (non-slave), because the free person is not a property, so it shall not be traded and shall not be guaranteed the debt;

b. If the object of the contract is something unclean, such as carcasses, dogs, and pigs. Also, all holy things that are turned into unclean that cannot be purified anymore, such as vinegar, milk and other liquids that are exposed to unclean. But if it can be cleaned, then it can be used as an object of agreement; c. If the object is a non-usable item, either that cannot be exploited in a tangible form, such as an insect or cannot be exploited because it is prohibited by sharia, such as a musical instrument. Because the legal function of a commodity is the basis of the value and price of the commodity. A useless commodity is like a junk that cannot be used. Or useful but for things that are forbidden, such as liquor and 
the like, all of them cannot make the object akad.

c. The object of the contract is present when the contract is committed;

d. The transaction object can be handed over. Goods that are absent or present but cannot be handed over, are not legitimate as objects of contract;

e. If the object is goods that are traded directly, then transactor must know its form. And must know the size, type and criteria, if the goods are in transactor ownership but the goods are not in the location of the transaction, as in the sale and purchase as-Salam, based on the words of the Prophet sallallaahu 'alaihi wa sallam, "Whoever does the buying and selling As-Salm, he should sell his goods in a clear measure or a clear scale, within a clear deadline. "

3. Transaction Sentence (shighat al-Akad).

The meaning is the expression or the representative of which is sourced from the transactor to indicate his desire for the sustainability of the transaction and at the same time implies his pleasure towards the contract. The scholars of the fiqih mention about ijab and qabul (handover). Business-related transactions under written provisions, in this case with regard to the contract on sharia business, do not rule out any legal problems that need to be resolved. The mindset of the people who still make all the settlement of legal problems through the court of the courts basically does not reflect the nature of nationalism and holds the ancestral value that solves the problem through consensus deliberation.

Indonesia uses a court handling system through courts with several courts having different duties of handling different cases, for example between the District Court and the Religious Courts. There are still many people who did not understand another role of the Religious Courts, becoming problematic in solving the existing case. For example, the Religious Courts are only known as dispute settlement sites for Muslim communities, whereas religious courts now have the function of handling cases for sharia economic disputes.

Another issue is the existence of several regulations related to the settlement of sharia economic cases that stipulate the settlement of cases outside the court (non-litigation), for example, related to the handling of sharia banking case. Based on Fatwa DSN-MUI No. 17/DSN-MUI/IX/2000 Concerning Sanctions on Client Able to Procrastinate Payment by way of fine, and final sanction is the settlement of case through National Sharia Arbitration Board after consultation.

Recently, the implementation of Fatwa in Indonesia itself becomes an interesting issue to be studied in various legal science discussions. It is due to his position which is deemed not to have strong legal binding force since it refers to the opinion of 
Mahfud MD, the former chairman of the Indonesian Constitutional Court, the fatwa is nothing more than a legal opinion that may be followed and may not be followed. From the point of view of abstract rules, new fatwas may be binding if they have been given certain legal forms by authorized institutions, such as being made into laws or local regulations so that it becomes a positive law.

In practice, there are people who are Muslims who want to implement the fatwa, this is a form of religious consciousness personally, not as a legal obligation. It can be concluded also that fatwa is concrete not binding as a whole, only has the purpose of regulating certain subjects only. Based on this background, this research will discuss the related Fatwa Function in Setting the Sharia Economic Dispute Settlement in Indonesia, based on the applicable national legal aspects.

\section{Problem Formulation}

Based on the description on the background, the author formulates of the problem that What is the legal basis of binding force of fatwa in managing the Sharia economic disputes in Indonesia through BASYARNAS and what is the impacts for the Islamic financial institutions (LKS), if they disobey the fatwa of $D S N$.

\section{B. THEORITICAL BACKGROUND}

\section{Definition of MUI Fatwa}

The Fatwa according to the Great Indonesian Dictionary ("KBBI") accessed from the Ministry of Education and Culture's Language Development and Language Development Website is a decision or opinion given by the mufti about a matter in other words that is the advice of the pious. While the meaning of the Indonesian Council of Ulama ("MUI") according to Presidential Regulation No. 151 of 2014 on Funding Assistance for the activities of the Indonesian Council of Ulama ("Perpres No. 151 Th 2014") is a venue of deliberations of ulama, leaders and Muslim intellectuals in protecting the Ummah and develop an Islamic life and increase the participation of Muslims in national development (Najib, 2012). Mohammad Daud Ali mentioned that MUI is a partner of the government in organizing an Islamic development development program (Mohammad Daud Ali, 2004).

\section{The position of Fatwa in Islamic Law}

The position of Fatwa in Islamic Law according to Mohammad Daud Ali, the sources of Islamic law are:

a. The Qur'an;

b. As-Sunnah (al-Hadith); 
c. The mind's mind (ra'yu) is qualified to berijtihad because of its knowledge and experience, by using various methods or means, among them are ijma', qiyas, istidal, al-masalih al-mursalah, istihsan, istishab, and urf.

Mohammad Daud Ali further explained that the method of ijtihad is:

a. Ijma '. Ijma 'is the approval or conformity of experts' opinion on the matter at a place at a time.

b. Qiyas. Qiyas is to equate the law of a thing that does not contain its provisions in the Qur'an and as-Sunnah or al-Hadith with things (other) whose law is mentioned in the Qur'an and the Sunnah of the Prophet (contained in the books of hadith ) because of the illat (cause or reason) equation.

c. Istidal. Istidal is drawing the conclusion of two different things. For example drawing conclusions from customs and religious laws that were revealed before Islam.

d. Change al mursalah. It is a way of discovering the law of a thing which is not found in both the Qur'an and in the books of hadith, based on the consideration of the benefit of society or the public interest.

e. Istisan. Istisan is a way of determining the law by deviating from existing provisions for justice and social interests.

f. Istishab. Istishab is establishing the law of things according to the circumstances that happened before, until there is a proposition that changed it.

g. 'Uf. 'Urf or custom which is not contrary to Islamic law can be confirmed to continue to apply to the people concerned (Ali, 2004).

Sulaiman Abdullah, mentions that the fatwa of friends is published on the basis of thought and ijtihad through a well-known and undisputed history, including in the category of ijma 'sukuty. Based on the explanations and opinions of some of the Islamic Law experts mentioned above, the fatwa is a provision of Islamic law issued on the basis of thought and ijtihad by means of ijma ', ie approval or conformity of opinion of experts on the problem in a place at a time.

3. The Status of the MUI Fatwa As a Legislation Regulation

Based on Article 1 Sub-Article 2 of Law Number 12 of 2011 regarding the Establishment of Legislation ("Law No. 12 of 2011") explains that the Laws and Regulations are written rules that contain binding norms in general and are established or established by state institutions or authorized officers through procedures established in the Laws and Regulations. The type and hierarchy of Legislation consists of:

a. 1945 Constitution of the State of the Republic of Indonesia;

b. Decision of the People's Consultative Assembly;

al-aḥkäm vol. 3, Nomor 2, 2018 
c. Law/Government Regulation in Lieu of Law;

d. Government Regulations;

e. Presidential Decree;

f. Provincial Regulations; and

g. Regency/City Regulations.

Types of Legislation Other than those mentioned above, include rules set by, among others:

a. Majelis Permusyawaratan Rakyat (MPR);

b. House of Representatives (DPR);

c. Regional Representative Council (DPD);

d. Supreme Court (MA);

e. Constitutional Court (MK);

f. Supreme Audit Agency (BPK);

g. Judicial Commission (KY);

h. Bank Indonesia (BI);

i. Minister;

j. A commission, body or commission of the same level established by law or Government on the order of the Act;

k. Provincial House of Representatives;

I. Governor;

m. Regency/Municipal House of Representatives;

n. Regent/Mayor;

o. Village Head or the same level.

If it refers to the type and hierarchy as mentioned in Law No. 12 of 2011 above, then the position of the MUI Fatwa is not a type of legislation that has binding legal force.

The position of the MUI and the MUI Fatwa in the Constitutional Perspective according to Ainun Najib is in the element of constitutional infrastructure, because MUI is the organization of Alim Ulama Umat Islam which has the duty and function for the empowerment of society (Moslem), meaning that MUI is an organization that exists in society, is a state-owned institution or represents the state. This means that the MUI fatwa is not a state law that has sovereignty that can be imposed on all people, MUI fatwa also has no sanction and should not be obeyed by all citizens. As a socio-political force existing in the constitutional structure, the MUI Fatwa is only binding and adhered to by the community of Muslims who feel they have a bond to the MUI itself. The legality of the MUI fatwa can not and can be forced to be obeyed by all Muslims. Ainun adds that the fatwa itself is essentially nothing more than an opinion and a mere thought, of the individual ulama or the institution of keulamaan, which may be followed or even ignored altogether. 
Moh. Mahfud MD argues that from the point of view of constitution and law, the fatwa of the Indonesian Council of Ulama (MUI) is not binding and can not be imposed through law enforcement. The fatwa is nothing more than a legal opinion that may be followed and may not be followed. If viewed from the perspective of an abstract rule, the new fatwa can be binding if it has been given a certain legal form by an authorized institution, for example made into law or local regulations so that it becomes a positive law. That there are Muslims who want to carry out the fatwa may be a religious conscience personally, not as a legal obligation. What is the position of the MUI fatwa before the court? According to Mahfud, that the MUI's Fatwa before the court can be used as a statement and/or expert opinion, even doctrine, in order to prove the concrete-individual case (in concreto), not as an abstracto-general rule.

Although the MUI Fatwa is not one of the types of legislation recognized in Indonesia according to Yeni Salma Barlinti in his dissertation conclusion entitled "The Status of the DSN Fatwa in the National Law System", which has been maintained in the examination of the Faculty of Law, University of Indonesia (FHUI) doctoral program, as quoted from the article Fatwa DSN Is a Binding Positive Law, explained that in its development, some fatwas issued by the National Sharia Council of Indonesian Council of Ulama (DSN-MUI) is a binding positive law. Because, its existence is often legitimized through legislation by government agencies, so should be adhered to the economic actors of sharia. So the MUI fatwa is not binding for citizens, but may be binding as long as it is absorbed into legislation.

\section{Overview of BASYARNAS}

The practice of dispute settlement through BASYARNAS in Indonesia has been started since 1993. The arbitration institution is chosen by the justice seekers because it has many advantages. The advantages of arbitration institutions compared to judicial institutions, among others, are: a simple, closed, fast and dignified examination process. The presence of BASYARNAS is actually a valuable contribution of Islamic law to the development of national law in the framework of the development of the Indonesian nation.

At the beginning of its establishment, the Indonesian Armed Forces (BAMUI) was established by the Indonesian Ulema Council (MUI) based on the decision of the National Working Meeting (MUI) in 1992. The change of name from BAMUI to BASYARNAS was decided in the $2002 \mathrm{MUI}$ National Congress. The change of name, BAMUI is contained in Decree No. MUI. Kep-09 / MUI / XII / 2003 dated December 24, 2003.

SK MUI No. Kep-09 / MUI / XII / 2003 Dated December 24, 2003 on National Sharia Arbitration Board which contains Basic Guidelines and Board Composition.

National Syariah Arbitration Board (BASYARNAS) at the time was established named Arbitrase Muamalat Indonesia (BAMUI). BAMUI was established on October 21, 1993 - 
incorporated as a foundation. The deed of establishment was signed by the Chairman of MUI Bp. KH. Hasan Basri and General Secretary Bp. HS. Prodjokusumo.

BASYARNAS in accordance with the Basic Guidelines established by the MUI: a free, autonomous and independent judiciary, shall not be interfered with by any power or parties. BASYARNAS is a tool of MUI organization as DSN (National Sharia Council), LP-POM (Institution for Institution, Supervision of Drugs and Food), YDDP (Foundation of Da'wah Development Fund).

\section{METHODE}

This research used socio-legal approach with qualitative tradition (Noeng Muhajir, 2002). The operationalization was done according to constructivism paradigm. Constructivism paradigm is a set of beliefs on a legal reality (Islamic banking) as a result of the construction which is relative, specific, and contextual in nature. The relative position (stand point) of the researchers on the problem in this study is at the level of epitome not as a participant but rather as an observer. As observers, the researchers will seek answers to any formulation of the problem posed by studying the reality of Islamic banking dispute settlement through mediation (construction's result) spread in legislation or related policies and their implementation in the religious court. The comprehensive understanding is obtained as the product of the interaction between the researchers with the observed object. There is a relatively subjective transactional relationship between the researchers and the research subjects. The researcher is the instrument, thus at the level of axiology the position of the researcher is as a facilitator that bridges the diversity of existing data and subjects.

The study was conducted with two strategies, namely library research and case study. Library study was conducted on all documents or literature about "Fatwa DSN MUI In Managig The dispute Settlement of sharia Economic in Indonesia Through BASYARNAS". The existing documents are then grouped according to the dimension of time or period. The case study in this research is the national case, particularly the case of Islamic banking disputes. The research with this case study is carried out to record the social facts that accompany the development of society in supporting and sustaining human needs in the field of economics in society.

This study uses the codes of socio-legal studies (Ricardo Simarma, 2007), i.e. understanding the law not merely as a normologic and esoteric normative entities. So that the law of Islamic banking in this study is understood as an entity which is heavily influenced by non-legal factors. The formulation of the substance or content, the choice of goals and the means used to achieve the objectives of Islamic banking or the dispute settlement are believed to be interaction with non-legal factors. 
Primary data were obtained through field research with observations, interviews, which includes: a. Law sanction institution: Arbiter in BASYARNAS DIY, Legal Section Staff at the Islamic Microfinance Institution, Advocate, Registrar. b. Role Occupant: Islamic Microfinance Management, Islamic Customers-done with hermeneutics, sociology of law and phenomenology.

Secondary data were obtained through the Library Research and Legal Document, which includes: Primary Law Materials, include: 1) Law No. 17 of 2012 concerning Cooperatives and its implementing regulations; 2 ) he Constitutional Court Decision No. 93/PUU-X/2012. Secondary Legal Materials, consisting of books about the legal system, the principles of law, legal theory, legal research methodology, and journals.

\section{RESULT AND DISCUSSION}

MUI fatwa is needed by the Islamic community as a guide or solution (solution) to a problem. The lecturer of Faculty of Law, Universitas Indonesia, Yeni Salma Barlinti, has conducted research on the Fatwa of the National Sharia Board of MUI. The National Sharia Council is one of the specialized MUI sections. The study result is Fatwa DSN-MUI is a binding positive law if it has been legitimized into legislation. The legitimacy is indeed mandated by the Act.

Legalizing MUI Fatwa may be justified insofar as it is recognized by the state. The fatwa that has been enforced by the state through legislation is binding. If you look at the law that prevails to today, there are some laws that order the publication of legal products generally by the MUI fatwa, for example is the Islamic Banking Law Number Year 2008. In the explanation of its consideration regulating, as a law that specifically regulates sharia banking, in this Law is regulated on compliance issues (shariah compliance) whose authority resides in Majelis Ulama Indonesia (MUI) represented through Sharia Supervisory Board (DPS) to be established in each Sharia Bank and Sharia Business Unit (UUS).

In addition to those that are restructured through legislation, fatwas need to be positioned as legal opinions, not a positive law in the context of the order of legislation. The Fatwa is the advice of ulama in answer to a problem. For example, when the Government and the public are aggressively fighting narcotics, the MUI comes with a Fatwa on Punishment for Manufacturers, Airports, Dealers and Narcotics Misuse. Chairman of the MUI, KH Ma'ruf Amin, in his paper "The Process of Formation and Issue of MUI Fatwa" (2017), writes fatwas is the answer to the problems and problems faced by Muslims who are increasingly complex and diverse. The fatwa is 'a way out that gives religious answers to emerging problems.

The role of the fatwa continues on the application of dispute settlement related to Islamic law enforcement in Indonesia. The application of legal settlement is for example by establishing clauses, settlement mechanisms through the National Sharia Arbitration

al-ạ̣kām Vol. 3, Nomor 2, 2018 
Board (BASYARNAS) as an attempt to settle disputes outside the court. Need to know, some countries use this system as a medium to accelerate the handling of cases because the settlement of cases through the court is considered less profitable seen from the efficiency of time, the cost of completion, even rarely the objection with the judge's decision, so as not to guarantee the dispute is not finished trial with a short time.

Studying the circumstances of neighboring Malaysia, arbitration dispute resolution is commonly used in Malaysia as an alternative of dispute resolution other than litigation through the court. The surge in international trade and cross-border transactions has also seen Malaysia as a popular regional and global place for the implementation of Sharia Arbitration. The revitalization of Kuala Lumpur Center for Arbitration (KLRCA), with its state-of-the-art facilities, also plays a leading role in spurring the growth of international arbitration in Malaysia.

Dispute resolution through Arbitration in Islam is not limited to economic, social, religious and political affairs but may also apply to private law but is limited to rights or obligations to certain individuals and not extended to corporal punishment (Singh, 2017). Based on research through 2014, KLRCA (Kuala Lumpur Regional Center for Arbitration) has been steadily increasing in its case every year. Prior to 2010, the number of cases enrolled in the KLRCA was between ten to 20 cases per year. In 2012, KLRCA recorded 85 new cases; in 2013 the proposed annual case has increased to 156 and by the third quarter of 2014, the center has received 226 cases. According to KLRCA statistics, almost $20 \%$ of arbitration cases in 2013 are international, a marked increase from previous years.

In addition, dispute settlement in Singapore also accommodates dispute settlement through Sharia Arbitration as one of the technical solutions of sharia law disputes in the country. Singapore also accommodates Mediation and Arbitration as part of the practice of Islamic law in the country. The norms of Islamic law are not deterred from arbitration provisions in the commercial context and in family matters, peaceful settlements are encouraged and even facilitated (Arif A Jamal, 2015).

The presence of the National Syariah Arbitration Board (BASYARNAS) previously known as the Indonesian Arbitration Board of Muamalat (BAMUI) is very much expected by Indonesian Muslims, not only because it is motivated by the awareness and interest of Muslims to implement Islamic sharia, but also more than that is the real need civil practice in peace in harmony with the development of economic and financial life among the ummah (Ummi Azma, 2014).

The practice of dispute settlement through BASYARNAS in Indonesia since its establishment until now is headquartered in Jakarta which is located at Arva Building Floor IV, Jl. Cikini Raya No. 60 Jakarta 10330, Phone: 0213144794 Fax: 021 3915479, Email: basyarnas-pusat@commerce.net.id. In addition to the headquarters, BASYARNAS office 
in the area there are 10 offices, namely BASYARNAS Riau, DIY, East Java, Central Java, Lampung, Cirebon, West Kalimantan, South Sulawesi, Central Sulawesi, South Sumatra. Special BASYARNAS DIY with offices at Jalan Kapas, No. 3 Yogyakarta to March 2018 has resolved the dispute of sharia economy as many as 13 cases.

The Procedure and Mechanism of National Sharia Arbitration Board (BASYARNAS) Majelis Ulama Indonesia (MUI) is as follows:

a) Public Request. The Arbitration Process begins with the registration of a petition for Arbitration by the Secretary in the Register of the National Sharia Arbitration Board (BASYARNAS). The petition must contain at least the full name and place of residence or place of the two parties, a brief description of the copy of the Arbitration treaty and a special power of attorney is filed by a legal representative;

b) Furthermore, the letter of application shall be examined by the National Syariah Arbitration Board (BASYARNAS), to determine whether the National Arbitration Board (BASYARNAS) has the authority to examine and adjudicate the arbitration dispute petitioned for;

c) The assigned arbitrator is instructed to submit a copy of the petition to the Respondent accompanied by an order to respond to the request and provide the written reply within 30 (thirty) days from the receipt of a copy of the application letter and the summons. Immediately upon receipt of the response of the Respondent, on the orders of the sole Arbitrator or the chair of the Arbitrator of the Assembly, a copy of the reply shall be submitted to the Petitioner and simultaneously instructs the parties to appear before the Arbitral Tribunal on the appointed date, not later than 14 (fourteen) days from the date of issuance of the order, with the notification that they may represent their respective legal counsel with a special power of attorney;

d) Arbitration proceedings shall be conducted at the seat of the National Sharia Arbitration Board (BASYARNAS), unless there is consent from both parties, the examination may be conducted elsewhere. A single arbitrator or assembly may conduct an on-site hearing to examine witnesses, goods or other documents relating to the parties to the dispute. Judgment must be taken and dropped at the seat of the National Syariah Arbitration Board (BASYARNAS);

e) During the process and at each stage of the examination the arbitrator shall be furnished or the assembly shall give equal equality before the law to defend and defend the interests of the disputed case;

f) A single arbiter or assembly, either on his or her own opinion or the parties may conduct hearings by hearing witness statements, including expert witnesses and oral examinations among the parties, any evidence or documents submitted by 
either party to a sole arbitrator or copy assembly shall be delivered to the opposing party. However, the examination is allowed orally (oral hearing). The examination phase begins with answer-answering (replic-duplic), verification and verdict are done based on the policy of a single Arbiter or assembly;

g) In the reply, or at the latest on the first hearing of the examination, the Respondent may file a reply (reconvention). With regard to the rebuttal filed by the Respondent, the Petitioner may submit a reply accompanied by additional Claim, provided that it has a very close relationship with the disputed subject and is included in the jurisdiction (BASYARNAS), both convention, reconvention and additional claim will be examined and decided by the Arbitrator or Arbiter Assembly will first seek to achieve peace;

h) A single arbiter or assembly shall adjourn an arbitration dispute and set a trial day to make a judgment, if it considers the examination sufficient, by not having the possibility of opening the examination once again before the judgment is imposed when deemed necessary;

i) Decisions are taken and decided in a session attended by both parties. If the parties have been properly summoned, but if no one is present, the verdict is still spoken. The whole process of the examination until the pronouncement of a decision by a single arbitrator or assembly shall be completed no later than 6 (six) months after the first call of the parties to the first hearing of the examination;

j) The arbitral award shall contain the grounds unless the parties agree to the decision not to make excuses. The Single Arbitrator or the Assembly shall decide upon propriety and expertise in accordance with the legal provisions applicable to the treaty which causes the dispute and is agreed upon by the parties. The verdict is final and binding on the parties to the dispute and the parties shall abide by the voluntary fulfillment referred to above. If the verdict is not fulfilled voluntarily, then the judgment is executed in accordance with the provisions of Article 637 of the Regulation op de Bourgerlijke Rechtsvordering (RV) and Article 639 (RV).

Based on the provisions of Article 26 of Law no. 21 Th. 2008 concerning Sharia Banking (Sharia Banking Law) that activities in the practice of sharia banking are subject to sharia principles. The Sharia Principles referred to is filed by MUI as outlined in the Bank Indonesia Regulation (PBI). Based on Article 26 of Sharia Banking Law, several PBIs are among others PBI No. 15/13/PBI/2013 concerning Amendment to PBI No. 11/3/PBI/2009 concerning Sharia Commercial Banks and PBI No. 15/14/PBI/2013 Amendment to PBI No. 11/10/PBI/2009 concerning Sharia Business Unit (UUS). PBI No. 9/19 / PBI / 2007 concerning Implementation of Sharia Principles in Funding Activities and Fund Distribution and Services of Bank Syariah. 
Based on the three PBI's, it is regulated on several notions of BUS, UUS, Aqad, Sharia Principles, Sharia Services which can be the basis for parties and communities that will bind themselves in sharia banking practices. Based on some provisions it is very clear that the position of MUI Fatwa in Islamic banking practices binding for the parties, especially in Islamic economic transactions.

Sharia economic transactions, especially sharia banking is based on Sharia contract as a source of engagement between the parties. The intend 'ed contract is an agreement which creates an obligation of achievement on one side and the right of the other for the achievement in mutual (Musjtari, 2016). Another legal basis underlying the binding of MUI Fatwa for the parties in the practice of sharia banking is based on the principle of binding of the contract is the principle of "mabda 'wujub al wafa' bi al 'aqad" or also known as Pacta Sunt Servanda principle. It is based on the Qur'an Surah Al-Isra 'verse 34 which means "... and fulfill the promise, indeed the promise must be held accountable". In the rule of Ushul Figh, Syamsul Anwar mentions that the command in principle shows mandatory. This means that the promise is binding and must be fulfilled (Anwar, 2010)

Binding Fatwa DSN MUI in the operationalization of sharia banking and LKS is based on Article 31 of Decree of Board of Directors of Bank Indonesia Number 32/34/1999. This means that if the Fatwa DSN MUI directs the settlement of the dispute through BASYARNAS should the parties in making the sharia contract also comply with the contents of Article 55 of the Islamic Banking Law, Supreme Court Regulation No. 1 and 14 Th. 2016 and Fatwa DSN MUI which regulates the sharia contract. Therefore, the clause in the sharia law, especially in the articles governing the settlement of disputes should be directed at dispute settlement by consensus agreement, Sharia Mediation, Sharia Arbitration through BASYANAS and Religious Court.

Related to maintaining compliance with the parties that will determine the clausa of dispute settlement on the contract, the role of DPS is very important. This is intended to impart efficiency and effectiveness at the time of manufacture, execution, and settlement of contract dispute on LKS practices. The consequences for LKS who do not comply with the content of the DSN Fatwa will have difficulty in carrying out its activities and affect the performance and credibility of DPS in LKS.

\section{E. CONCLUSION}

Fatwa DSN MUI needs to be positioned as a legal opinion, not merely a positive law in the context of the order of legislation. The Fatwa is an advice of Ulama in answering people problem. The position of the DSN Fatwa in the ljtihad series can be categorized as ljma 'and in the order of legislation as the Doctrine. However, considering the existence of Fatwa DSN MUI in the operation and settlement of disputes that have been regulated in the

al-aḥkām vol. 3, Nomor 2, 2018 
Islamic Banking Law and PBI, the existence of Fatwa DSN MUI is binding on the parties in sharia banking practices and LKS.

The legal basis of DSN Fatwa's power in regulating the settlement of Sharia Banking disputes is based on Article 26 of Law no. 21 Th. 2008 and Article 31 of Decree of the Board of Managing Directors of Bank Indonesia Number 32/34/1999. The consequences for LKS who do not comply with the content of the DSN Fatwa will have difficulty in carrying out its activities and affect the performance and credibility of DPS in LKS.

\section{REFERENCES}

Ahmad Rafiq. (2015). Hukum Perdata Islam di Indonesia. Jakarta: PT RajaGrafindo.

Anwar, S. (2010). Hukum Perjanjian Syariah. Jakarta: Rajawali Pres.

Arif A Jamal. (2015). ADR and Islamic Law: The Cases of The UK and Singapore.

Mahfud MD. (2016). Bahasa Hukum, Fatwa dan Hukum Positif Kita. Http://www. hukumonline.com.

Mardani. (2015). Sistem Hukum Ekonomi Islam. Jakarta: PT RajaGrafindo.

Mohammad Daud Ali. (2004). Hukum Islam: Pengantar Ilmu Hukum dan Tata Hukum Islam di Indonesia. Jakarta: PT RajaGrafindo.

Musjtari, D. N. (2016). Penyelesaian Sengketa Akad dengan Jaminan Hak Tanggungan dalam Praktik Perbankan Syariah. Yogyakarta: Parama Publishing.

Najib, A. (2012). Fatwa Majelis Ulama Indonesia dalam Perspektif Hukum Responsif. Lisan Al-Hal, 4.

Noeng Muhajir. (2002). Metodologi Penelitian Kualitatif. Yogyakarta: Rakesarasin.

Rajafi, A. (2013). Masa Depan Hukum Bisnis Islam Indonesia. Yogyakarta.

Ricardo Simarma. (2007). Socio-Legal Studies and Legal Reform Movement in the Law Digest. Society and Development, 1.

Singh, V. (2017). Alternative Dispute Resolution in Islam: An Analysician. ILI Law Review, 1(Summer).

Ummi Azma. (2014). Implementation or Execution of Decision of National Syariah Arbitration Board (Basyarnas) As the Authority of Religious Courts. Law and Development. 
